\title{
ELISA and Neutralising Antibody Development in 27 Kenyan Horses after Vaccination with Inactivated African Horse Sickness Vaccines Containing All 9 Serotypes
}

\author{
Wernery $\mathrm{U}^{1 *}$, Joseph $\mathrm{S}^{1}$, Raghavan $\mathrm{R}^{1}$, Spendrup $\mathrm{S}^{2}$ and Dyer $\mathrm{B}^{2}$ \\ ${ }^{1}$ Central Veterinary Research Laboratory, P.O. Box 597, Dubai, UAE \\ ${ }^{2}$ Kisima Farm, Nanyuki 10400, Kenya \\ *Corresponding author: Wernery U, Central Veterinary Research Laboratory, P.O. Box 597, Dubai, UAE; E-Mail: cvrl@cvrl.ae
}

Received: March 21, 2021; Accepted: April 05, 2021; Published: April 08, 2021

\begin{abstract}
Twenty-seven horses were simultaneously vaccinated against all 9 African Horses Sickness (AHS) serotypes in 2 injections and their seroconversion was recorded after several years. Sixteen horses which were regularly immunized with the Onderstepoort attenuated vaccine (OBP) until 2013 and then annually 6 times until 2019 with the inactivated CVRL vaccine, developed high ELISA and VN antibodies. Ten horses which never received the OBP vaccine but since 2015 six times the CVRL vaccine also had developed ELISA and VN antibodies which, however were lower than in the first group.

This shows that multiple vaccinations against all 9 AHS serotypes are important for the development of high antibody levels. It also seems to be an advantage to vaccinate horses with the inactivated vaccine which had been previously immunized with the OBP vaccine, as this approach will induce high levels of antibodies.
\end{abstract}

\section{Introduction}

African Horse Sickness is an insect borne viral disease of equids that is endemic to sub-Saharan African countries [1,2]. It is caused by the AHS virus (AHSV) of the genus Orbivirus in the family Reoviridae. Culicoides (C.) spp midges are the principal vectors of all 9 serotypes and C. imicola is the most important midge for the AHSV transmission [3]. There is no treatment for AHS available, but prevention can be achieved by vector control and vaccination. Vaccination is the most effective way of bringing the disease under control and vaccination was used successfully during the Spain outbreak between 1987 and 1991 [4]. First attempts to control AHS by vaccination dates back to the beginning of the last century by using commercially live, attenuated vaccines even until today, which provide strong humoral and cell immunity. Neutralising antibodies reflect the horses' immunity [5] and protection against AHS is serotype specific, which means that horses must be immune to all 9 serotypes. However, to ensure a polyvalent immunity against all 9 serotypes, horses need at least 3 to 4 annual vaccinations $[5,6]$.

There is increasing concern regarding the use of attenuated vaccines because of their potential reversion to virulence by re-assortment of their gene segments with other vaccine and field serotypes which were reported [7,8]. Similar drawbacks of attenuated Orbivirus vaccines are known from attenuated Bluetongue (BT) vaccines, which even may cause abortion and congenital malformations when pregnant ewes are vaccinated. It was also discussed that clinical signs may be caused in some sheep breeds by the vaccine virus itself with a viraemia in the vaccinates. These vaccine viruses may then consequently be transmitted in the field by midges meeting field strains and then reassort to produce new virus strains. Consequently, the widespread use of such attenuated vaccines against BT was not recommended and the recent BTV-8 outbreak in Europe was controlled using inactivated vaccines $[9,10]$.

The aim of this vaccination experiment was to evaluate the serological response of 27 Kenyan horses from the field with a different vaccination history.

\section{Material and Methods}

\section{Horses}

Twenty-seven horses which were kept in the Laikipia area of Kenya were selected for this AHS vaccination experiment. During the day all horses were grazing together in open undulating Savannah and during the night they were kept near a homestead in open fenced areas under acacia trees. Horses were divided in 2 groups. Sixteen horses (116) had been regularly vaccinated with the Onderstepoort attenuated OBP vaccine until 2013. Thereafter, since 2014, they received only the inactivated CVRL vaccine as an annual vaccination, in total 6 times. Ten horses (17-27) never received the OBP vaccine and only since 2014 the CVRL vaccine, in total also 6 times. 


\section{Vaccine}

Over a period of 17 years all 9 AHS serotypes were isolated at CVRL from horse fatalities in Kenya. These serotypes were chemically inactivated by BEI and formalin, ultra-filtrated and used for this vaccine experiment which is described earlier $[11,12]$. The inactivated vaccine comes in 2 shots which are simultaneously and subcutaneously (sc) injected into the left and right side of the horses' necks. Shot 1 contains serotypes $1,4,7,8,9$ and shot two 2,3,5,6.

\section{Serology}

Four weeks after the last annual booster in September 2019, blood was withdrawn from the jugular vein of all 27 horses and tested for AHS antibodies with the competitive ELISA and the virus neutralization test (VNT) which are both described in details [13]. Serum samples showing blocking percentage (Percentage inhibition, PI) values lower than $45 \%$ were considered negative, whereas samples above $50 \%$ were considered positive. Serotype specific antibodies which were tested with the VNT were according to the SpearmanKarber method expressed as negative $\log _{10}$

\section{Results}

Results of this vaccination experiment are shown in Tables 1 and 2. Group 1 which consisted of 16 horses (1-16) received the South African vaccine until 2013 and then annually the CVRL vaccine 6 times until 2019. Horses had developed high ELISA and VN antibodies. The mean ELISA antibody result of these horses was $93 \%$ PI, whereas the mean VN antibody result were between 3 and $4 \log _{10}$.

Table 1: ELISA and VN antibodies of 16 Kenyan horses vaccinated until 2013 with the attenuated OBP vaccine and 6 times until 2019 with the inactivated CVRL AHS vaccine containing all 9 serotypes.

\begin{tabular}{|c|c|c|c|c|c|c|c|c|c|c|c|}
\hline \multirow{2}{*}{$\begin{array}{c}\text { Sl. } \\
\text { No. }\end{array}$} & \multirow{2}{*}{ Name } & \multirow{2}{*}{$\begin{array}{c}\text { ELISA }^{*} \\
\text { Jul-19 }\end{array}$} & \multicolumn{9}{|c|}{ VNT $^{* *}$ (Serotypes) } \\
\hline & & & 1 & 2 & 3 & 4 & 5 & 6 & 7 & 8 & 9 \\
\hline 1 & Bali & 94 & 2.5 & 2.5 & 4.75 & 4.25 & 2.3 & 3 & 3.75 & 2.5 & 5.5 \\
\hline 2 & Bilisa & 94 & 3.25 & 2.75 & 3 & 3.5 & 3 & 3.3 & 3 & 4 & 3.5 \\
\hline 3 & Boo & 94 & 3.5 & 3.5 & 4.25 & 3.75 & 3.5 & 3.3 & 2.5 & 4 & 4 \\
\hline 4 & Comanche & 93 & 3.75 & 3.75 & 3.25 & 3.5 & 2.5 & 3.8 & 3 & 3 & 3.5 \\
\hline 5 & Diane & 93 & 2.5 & 3 & 4 & 3.25 & 3 & 3 & 2.75 & 3.8 & 3.75 \\
\hline 6 & Joker & 93 & 2.5 & 2.5 & 4 & 5 & 3 & 3.8 & 3.75 & 3 & 4.5 \\
\hline 7 & Kalahari & 93 & 4 & 3.5 & 4 & 4 & 3.8 & 3.8 & 3 & 4 & 4 \\
\hline 8 & Punches Town & 94 & 4 & 3.75 & 4 & 2 & 3 & 2 & 3 & 4 & 5 \\
\hline 9 & Starlight & 93 & 3 & 3.25 & 3.25 & 3.75 & 2.8 & 3 & 1.75 & 3.8 & 2.75 \\
\hline 10 & Tiva & 93 & 2 & 3 & 4.5 & 4.5 & 3.3 & 3.8 & 3.5 & 3.3 & 5.25 \\
\hline 11 & Masala & 94 & 3.25 & 2.5 & 4.75 & 4.75 & 3 & 3 & 3 & 4 & 4.5 \\
\hline 12 & Suerte & 93 & 2.25 & 2.75 & 4.5 & 4 & 4 & 4.3 & 3.75 & 3.3 & 6 \\
\hline 13 & Marion & 94 & 2.5 & 2.75 & 4 & 4.5 & 2.3 & 3.8 & 3 & 2.5 & 4.25 \\
\hline 14 & Sandpiper & 91 & 2 & 2.25 & 3.75 & 3.75 & 3 & 3.3 & 3.5 & 2.3 & 5 \\
\hline 15 & Picassa & 93 & 4.25 & 3.75 & 4.25 & 5.5 & 3.5 & 3.8 & 4 & 4 & 5 \\
\hline 16 & Douglas & 93 & 2 & 2.25 & 3 & 2.5 & 2.3 & 2.3 & 4.5 & 2.3 & 5.25 \\
\hline & Mean & 93 & 3 & 3 & 4 & 4 & 3 & 3 & 3 & 3 & 4 \\
\hline $\begin{array}{l}\text { *ELIS } \\
\text { are st } \\
\text { in ye }\end{array}$ & $\begin{array}{l}\text { SA is expressed } \\
\text { hown in green } \\
\text { llow colour. }\end{array}$ & $\begin{array}{l}\text { s Perce } \\
\text { olour. }\end{array}$ & & & (PI\% & and & t-ofl & & or EI & & $\begin{array}{l}0 \% \\
\text { hown }\end{array}$ \\
\hline
\end{tabular}

Table 2: ELISA and VN antibodies of 10 Kenyan horses vaccinated 6 times with the inactivated CVRL AHS vaccine containing all 9 serotypes.

\begin{tabular}{|c|c|c|c|c|c|c|c|c|c|c|c|}
\hline \multirow{2}{*}{$\begin{array}{l}\text { Sl. } \\
\text { No. }\end{array}$} & \multirow{2}{*}{ Name } & \multirow{2}{*}{$\begin{array}{c}\text { ELISA }^{*} \\
\text { Jul-19 }\end{array}$} & \multicolumn{9}{|c|}{ VNT $^{* *}$ (Serotypes) } \\
\hline & & & 1 & 2 & 3 & 4 & 5 & 6 & 7 & 8 & 9 \\
\hline 17 & Scorpio & 90 & 2.25 & 2.25 & 2 & 2 & 1.8 & 2.75 & 0.25 & 2 & 3.25 \\
\hline 18 & Piper & 75 & 2.25 & 2.75 & 1.75 & 2 & 1.8 & 3 & 1.25 & 3 & 2.25 \\
\hline 19 & Hidalgo & 93 & 3.25 & 2.75 & 4 & 3.5 & 2.5 & 3.25 & 1.5 & 3.75 & 4 \\
\hline 20 & Hubblebubble & 80 & 2.25 & 2.75 & 2 & 5.5 & 3.5 & 2.5 & 1.5 & 2 & 2.5 \\
\hline 21 & Chelsea & 91 & 1.25 & 0.25 & 2.5 & 2 & 2.3 & 2.25 & 0.25 & 2 & 5.25 \\
\hline 22 & Kerry & 89 & 2 & 2 & 2 & 2 & 2.3 & 2.25 & 0.25 & 1.25 & 3.75 \\
\hline 23 & Alison & 62 & 2.25 & 3.5 & 2.5 & 2.25 & 1.8 & 2.25 & 1 & 3 & 2 \\
\hline 24 & Suni & 87 & 2.25 & 2.75 & 2.25 & 2 & 1.3 & 2 & 2 & 3 & 1.75 \\
\hline 25 & Kibiriti & 90 & 1 & 0.5 & 2.75 & 2 & 2.3 & 2.25 & 0.25 & 1.5 & 3.5 \\
\hline 26 & Makaa & 92 & 2 & 2 & 2.25 & 3.5 & 1.8 & 2.25 & 1 & 2.75 & 2 \\
\hline \multirow[t]{2}{*}{27} & Toby & 88 & 1.5 & 1.25 & 2.5 & 3 & 2.3 & 2.5 & 0.25 & 1.75 & 3.25 \\
\hline & Mean & 85 & 2 & 2 & 2 & 3 & 2 & 2 & 1 & 2 & 3 \\
\hline \multicolumn{12}{|c|}{$\begin{array}{l}\text { "ELISA is expressed as Percentage Inhibition (PI\%) and cut-off value for ELISA } \geq 50 \% \\
\text { are shown in green colour. "VNT results are expressed in } \log 10 \text { and titres } \geq 1 \text { are shown } \\
\text { in yellow colour. }\end{array}$} \\
\hline
\end{tabular}

Horses of group 2 comprising of 10 horses (17-27) which had received only the CVRL vaccine 6 times until 2019 also developed ELISA and VN antibodies which were, however lower than in the first group. Their mean values for ELISA antibodies were 85\% PI and their VN antibodies stood between 1 and $3 \log _{10}$.

\section{Discussion}

Inactivated vaccines for the protection of horses from AHS were previously successfully used to control an AHS serotype 9 outbreak in Spain [14] and in a vaccination and challenge experiment with serotype 4 [15]. However, to the knowledge of the authors, so far, no vaccination experiment had been conducted with an inactivated vaccine containing all 9 serotypes in 2 injections. Vaccination trials are currently carried out in Dubai with an inactivated vaccine containing all 9 AHS serotypes in one injection. The results of this study show that multiple vaccinations against all 9 serotypes are essential for the development of high ELISA and $\mathrm{VN}$ antibodies. Horses showing high $\mathrm{VN}$ antibodies between 1 and $2 \log _{10}$ and above seem to be immune against an AHS infection [16], but the absence of detectable $\mathrm{VN}$ antibodies to one or more serotypes may not always necessarily be suggestive of lack of protection against AHS, as these animals might appear to be resistant to a challenge which also may depend on a cell mediated immunity [17].

Ten horses in the second group which did not receive the OBP vaccine, but 6 times the inactivated CVRL vaccine like the first group developed lower ELISA and VN titres. This seems to indicate that it is an advantage to vaccinate horses with inactivated AHS vaccines which had been immunised with an attenuated vaccine.

\section{Conclusion}

Multiple vaccines against all 9 AHS serotypes are essential for the development of high and protective antibodies against AHS. It seems to be an advantage to immunize horses with the CVRL inactivated AHS vaccines that had been previously immunised with an attenuated vaccine as these horses produce high ELISA and VN antibodies. 


\section{References}

1. Coetzer J, Guthrie AJ (2004) African Horse Sickness. In: Infectious Diseases of Livestock, ed Coetzer J, Tustin RC 2nd edition, Volume 2 Oxford University. pp. 12311246.

2. Zientara St (2010) African horse sickness. In: Infectious and Parasitic Diseases of Livestock, ed Lefèvre, P.-Ch, Blancou J, Chermette R, Uilenberg, G. Volume 1, Lavoisier, pp 689-704.

3. Guthrie AJ, Quan, M (2009) African Horse Sickness. In: Infectious diseases of the horse, ed Mair TS, Hutchinson RE. A Peer-Reviewed Publication, pp. 72-82.

4. Rodgriguez M, Hooghuis H, Cartano, M (1992) African horse sickness in Spain. Vet Microbiology 33, 129-142. [crossref]

5. van Dijk AA (1999) African Horse Sickness vaccine development. In: Equine infectious diseases VIII ed. Wernery U, Wade JF, Mumford JA, Kaaden, O. R. R and W Publications, Newmarket, UK, pp. 261-265.

6. Zientara S, Weyer CT, Lecollinet, S (2015) African horse sickness. Rev Sci Tech Off Int Epiz 34(2), 315-327. [crossref]

7. Weyer C Th (2016) African horse sickness outbreak investigation and disease surveillance using molecular techniques. Doctoral thesis, University Pretoria, South Africa.

8. Weyer CT, Grewar JD, Burger, Ph, Rossouw E, Lourens C, et al. (2016) African Horse Sickness caused by genome reassortment and reversion to virulence of live, attenuated vaccine viruses, South Africa, 2004-2014. Emerg Inf Dis 22(12): 20872096. [crossref]
9. European Medicines Agency (2009) mail@emea.europa.eu https://www.ema.europa. $\mathrm{eu} / \mathrm{en}$

10. Lefèvre $\mathrm{PCh}$, Mellor, $\mathrm{Ph}$, Saegerman, $\mathrm{Cl}$ (2010) Bluetongue. In: Infectious and Parasitic Diseases of Livestock, ed. Lefèvre, P.-Ch, Blancou J, Chermette R, Uilenberg, G. Volume 1, Lavoisier, pp. 663-688.

11. Rodriguez M, Joseph S, Pfeffer M, Raghavan R, Wernery, U (2020) Immune response of horses to inactivated African horse sickness vaccines. $B M C$ (in press) [crossref]

12. Wernery U, Joseph S, Elizabeth, Sh. K, Patteril NG, Wernery R, Spendrup, S (2016) Production of an African Horse Sickness killed vaccine containing all 9 serotypes. 10th IEIDC Abstracts/Journal of Equine Veterinary Science 39, S101-S102.

13. OIE, Manual of Diagnostic Tests and Vaccines for Terrestrial Animals (2018) African Horse Sickness, 8th edition, OIE, pp. 1237-1252.

14. Lubroth, J (1988) African horse sickness and the epizootic in Spain in 1987. Equine Pract 10, 26-33.

15. House J, Lombard M, Dubourget P, House C, Mebus, C (1992) Efficacy of an inactivated African horse sickness serotype 4 vaccine. In: Bluetongue, African Horse Sickness and related Orbivirus: Proc Of the Sec Int Symposium, Eds. Walton TE, Osburn BI. CRC Press, Boca Raton, Florida, USA, pp. 891-895.

16. Lelli R, Molini U, Ronchi GF, Rossi E, Franchi P, et al. (2013) Inactivated and adjuvanated vaccine for the control of the African horse sickness virus serotype 9 infection: evaluation of efficacy in horses and guinea-pig model. Vet Italiana 49(1), 89-98. [crossref]

17. Hamblin C, Mellor PS, Graham SD, Hooghuis H, Montejano RC, et al. (1991) Antibodies in horses, mules and donkeys following monovalent vaccination against African horse sickness. Epidemiol Infect 106, 365-371. [crossref] 